\title{
2 \\ On the Road to Improved Social and Economic Welfare: The Contribution to Australian Competition and Consumer Law and Policy Law Reform
}

\section{Russell Miller $\mathrm{AM}^{\dagger}$}

The Australian Law Reform Commission's role is to review Australia's laws to ensure they provide improved access to justice for all Australians by making laws and related processes more equitable, modern, fair and efficient. ${ }^{2}$ While the Commission has an excellent record in addressing access to justice issues, in their many guises, access to justice is only one aspect to law reform.

The essential focus of law reform is on contributing to an Australian society that is more equitable, modern, fair and efficient. Or, to put it in the language of economists, to improve both consumer welfare and producer welfare through competition and consumer protection laws that are fair, open, efficient and effective. This is no easy task in any area of law reform and the economic area is no exception.

1 Member, Minter Ellison Australasian Competition Group; Fellow, Centre for Strategy and Governance; Fellow of the Australian Academy of Law.

2 Australian Law Reform Commission Act 1996 (Cth) s 21. 
Nevertheless, Australia has come a long way with competition and consumer protection law reform in the past 25 years, and that journey continues. I will demonstrate this by reference to three examples: a competition law example from the past, a more recent consumer law example, and a new horizon competition law example.

Before I do so I should observe that, while we all accept as self-evident the contribution consumer protection law makes to goals of equity, transparency and fairness, the same may not be said for competition law.

We value competition not for its own sake, but because it provides a flexible set of rules to promote efficiency and fair business dealings, thereby enhancing the welfare of all Australians. ${ }^{3}$ While competition rules do not always work in the way some would like, every modern market economy sees benefit in a set of equitable rules intended to ensure that competitive processes are not undermined by anticompetitive behaviour. In short, we value competition because it fosters opportunity, innovation, productivity and growth, thereby creating national wealth. ${ }^{4}$

For the purposes of this chapter, our journey on the road to improved social and economic welfare in Australia through competition and consumer law reform starts with a competition example drawn from the 1990 s. ${ }^{5}$ At that time Australia had fallen behind other developed countries, in part because our economy was, as the then Chair of the Productivity Commission, Professor Gary Banks, explained, ${ }^{6}$ 'highly regulated, anti-competitive and redistributive: captured nicely by the expression "protection all round" - a policy that for much of the last century had bi-partisan support and wide community acceptance'.

As Professor Banks pointed out, ${ }^{7}$ Australia had the highest per capita income in the world at the start of the $20^{\text {th }}$ century, but this had steadily declined. There were many causes for that decline, but for the purposes of this chapter I will concentrate on one - the limited reach of

3 The object of the Competition and Consumer Act 2010 (as with the Trade Practices Act 1974 before it) is to 'enhance the welfare of Australians through the promotion of competition and fair trading and provision for consumer protection', $\mathrm{s} 2$.

4 See, for example, Nick Godfrey, Why is Competition Important for Growth and Poverty Reduction?, OECD Global Forum on Investment, March 2008, 3.

5 In fact it started in the early 1900s. See Miller's Australian Competition Law and Policy (Thomson Reuters $2^{\text {nd }}$ edn, 2012) 1.

6 Gary Banks, Structural Reform Australian-Style: Lessons for Others? Presentation to the IMF and World Bank (Washington DC, 26-27 May 2005) and OECD (Paris, 31 May 2005) 2.

7 Ibid. 2. 
competition law. ${ }^{8}$ By 1993, although competition laws had applied to Australian businesses for almost 20 years, the competition law did not apply to federal and state statutory authorities that provided public utility and other services, sometimes on a monopoly basis and sometimes in competition to others. ${ }^{9}$ They did so, Professor Banks said, by and large on the basis that their 'fair' prices incorporated the cost of poor management and labour practices. ${ }^{10}$

In October 1992 the then Prime Minister, with the agreement of the states and territories, commissioned a panel, led by Professor Fred Hilmer, to review national competition policy and law, giving effect to principles including:

- No participant in the market should be able to engage in anticompetitive conduct against the public interest.

- As far as possible, universal and uniformly applied rules of market conduct should apply to all market participants regardless of the form of business ownership.

- Any changes to the coverage or nature of competition policy should be consistent with, and support, the general thrust of reforms:

- to develop an open, integrated domestic market for goods and services by removing unnecessary barriers to trade and competition; and

- in recognition of the increasingly national operation of markets, to reduce complexity and eliminate administrative duplication.

In August 1993, the panel's report recommended what was then regarded as very radical law reform across a spectrum of competition policy areas. For the purposes of this example I will focus on a few. First, the report recommended that the exemption from competition laws that then applied to government businesses should be removed, and that competition law should extend to sectors of the economy, such as professions, not then

8 Australia had had statutes addressing competition law since 1906, but modern competition law in Australia has its origins in the Trade Practices Act 1974.

9 The Industry Commission (now the Productivity Commission) undertook major studies of rail transport (1991), energy generation and distribution (1991) and water resources (1992), concluding that, in those industries alone, efficiencies could increase gross domestic product by $\$ 8$ billion per annum: National Competition Policy: Report by the Independent Committee of Inquiry, 23 August 1993 (the 'Hilmer Report'), 129.

10 Banks, above n 6. 
covered by the law. ${ }^{11}$ Second, it recommended pro-competitive structural reform of public utilities, with the separation of regulatory and business functions, and vertical separation of integrated utilities.

Both recommendations were based on the firm conviction that, by increasing competition, including by removing regulatory restrictions, restructuring public monopolies and applying competition law to sectors of the economy not then subject to the law, Australia would be a more equitable, modern, fair and efficient society. As the Hilmer Report stated: ${ }^{12}$

if Australia is to prosper as a nation, and maintain and improve living standards and opportunities for its people, it has no choice but to improve the productivity and international competitiveness of its firms and institutions. Australian organisations, irrespective of their size, location or ownership, must become more efficient, more innovative and more flexible.

The Hilmer Report's recommendations were accepted by all Australian governments and implemented through law reform projects that saw significant changes to the national competition law. Complementary state and territory laws ${ }^{13}$ were introduced to apply competition law to areas of the economy where the Commonwealth lacked constitutional competence. Unprecedented reform of state and territory statutory utility regulation was implemented, leading in some cases to privatisation and in others to corporatisation, assisted by compensation payments by the Commonwealth.

One measure of the success of this law reform initiative, and all the other initiatives that surrounded it, was that Australia's economic ranking internationally had risen from $15^{\text {th }}$ in 1990 to $8^{\text {th }}$ in $2002 .{ }^{14}$ But, far more importantly, this law reform initiative and the policies that accompanied it radically and permanently improved the welfare of all Australians.

11 The Hilmer Report, ibid. 124-39.

12 Ibid. 1.

13 Uniform Competition Policy Reform Acts; for example, Competition Policy Reform (New South Wales) Act 1995.

14 Banks, above n 6, 9. According to Banks, Australia had been number 5 in 1950. Australia's ranking in per capita incomes had slipped by the late 1980 s from $12^{\text {th }}$ to $16^{\text {th }}$. 
In 2004 the then federal treasurer requested the Productivity Commission to review the results of Hilmer reforms. In its report, released in February $2005,{ }^{15}$ the Commission reported that: ${ }^{16}$

National Competition Policy (NCP) has delivered substantial benefits to the Australian community which, overall, have greatly outweighed the costs. It has:

- contributed to the productivity surge that has underpinned 13 years of continuous economic growth, and associated strong growth in household incomes;

- directly reduced the prices of goods and services such as electricity and milk;

- stimulated business innovation, customer responsiveness and choice; and

- helped meet some environmental goals, including the more efficient use of water.

The second example of improved social and economic welfare in Australia through competition and consumer law reform is in the consumer law field.

Australia has a strong tradition in consumer protection but, until the introduction of the Trade Practices Act in 1974, consumer protection had been the sole province of state and territory governments. While the Trade Practices Act made an important contribution to consumer protection and fair trading, constitutional limitations meant that it could not cover the field. The result was a patchwork of state and territory laws. While the Trade Practices Commission ${ }^{17}$ pursued consumer complaints vigorously ${ }^{18}$ within the limits of its authority, a range of consumer affairs departments and agencies administered the rest with varying degrees of success.

In December 2006, the then treasurer requested the Productivity Commission to undertake an inquiry into Australia's consumer policy framework. The terms of reference included: ${ }^{19}$

15 Productivity Commission, Review of National Competition Policy Reforms, No 33, 28 February 2005.

16 Ibid. xii.

17 Now the Australian Competition and Consumer Commission.

18 See, for example, the cases brought by the ACCC under ss 52 and 53 of the Trade Practices Act up to 2010 digested in Miller's Annotated Trade Practices Act-Australian Competition and Consumer Law (Thomson Reuters $31^{\text {st }}$ edn, 2010).

19 Productivity Commission Inquiry Report No 45, 2008: Review of Australia's Consumer Policy Framework, vi. 
- ways to improve the consumer policy framework so as to assist and empower consumers, including disadvantaged and vulnerable consumers, to meet current and future challenges, including the information and other challenges posed by an increasing variety of more complex product offerings and methods of transacting;

- any barriers to, and ways to improve, the harmonisation and coordination of consumer policy and its development and administration across jurisdictions in Australia, including ways to improve institutional arrangements and to avoid duplication of effort;

- any areas of consumer regulation which are unlikely to provide net benefits to Australia and which could be revised or repealed.

The law reform objective in this, as in other areas of the law, was to advise on improvements that would benefit the community as a whole. That means, in the context of consumer protection, improving protections for consumers but only where the improvements produce a net benefit when weighed against the cost regulation imposes on society.

The Productivity Commission reported in 2008, concluding that: ${ }^{20}$

While Australia's consumer policy framework has considerable strengths, parts of it require an overhaul.

- The current division of responsibility for the framework between the Australian and State and Territory Governments leads to variable outcomes for consumers, added costs for businesses and a lack of responsiveness in policy making.

- There are gaps and inconsistencies in the policy and enforcement tool kit and weaknesses in redress mechanisms for consumers.

- These problems will make it increasingly difficult to respond to rapidly changing consumer markets, meaning that the associated costs for consumers and the community will continue to grow.

Addressing these problems will have significant direct benefits for consumers. Also, by better engaging and empowering consumers and furthering the development of nationally competitive markets, reform will enhance productivity and innovation.

The result was the most comprehensive law reform initiative in the consumer protection field that Australia had ever seen. The Productivity Commission's report was so persuasive that the federal, state and territory 
governments all agreed to embark on the creation of a national consumer law. The result was the Australian Consumer Law, introduced in an innovative way as a Schedule to the renamed Trade Practices Act - the Competition and Consumer Act - as a free-standing code, ${ }^{21}$ then applied in each state and territory by complementary legislation. ${ }^{22}$

In addition to repeating the provisions of the old Trade Practices Act in relation to misleading and deceptive conduct and false representations - provisions that had in any event been largely duplicated in state and territory law ${ }^{23}$ - the Australian Consumer Law expanded and upgraded coverage. This includes a nationally consistent law on unfair contract term ${ }^{24}$ and on unconscionable conduct, ${ }^{25}$ an upgrade of statutory implied warranties to consumer guarantees, ${ }^{26}$ stronger product safety laws, ${ }^{27}$ and detailed laws on door-to-door, internet and over-the-phone selling. ${ }^{28}$

This law reform measure produced a more equitable, modern, fair and efficient commercial and trading environment for consumers and traders alike: the Productivity Commission assessed the net benefit to Australia in monetary terms and concluded that the economic gain to the community by implementing its recommendations would be between $\$ 1.5$ billion and $\$ 4.5$ billion each year. ${ }^{29}$ But there is little doubt that the contribution to a fairer, more equitable Australian society was the major benefit.

A third example of improved social and economic welfare through competition and consumer law reform - the 'new horizon' competition law example - is law reform in the making. Although I will briefly describe what has been proposed and has subsequently been enacted, my primary reason for raising this example is to highlight the difficulties often encountered in the law reform process.

21 Schedule 2 to the Competition and Consumer Act 2010, applied as a law of the Commonwealth under Pt XI of that Act.

22 For a list, see Miller's Australian Competition and Consumer Law Annotated (Thomson Reuters $38^{\text {th }}$ edn, 2016) 1470 .

23 See, for example, Fair Trading Act 1985 (Victoria), Fair Trading Act 1987 (NSW).

24 Originally introduced in Victoria and now Pt 2-3 of the Australian Consumer Law. This law is to be extended to small business contracts from 12 November 2016.

25 Now Pt 2-2 of the Australian Consumer Law.

26 Part 3-2, Div 1 of the Australian Consumer Law.

27 Part 3-3, Div 1 of the Australian Consumer Law.

28 Part 3-2, Div 2 of the Australian Consumer Law.

29 Productivity Commission Inquiry Report No 45, 2008, 3. 
On 27 March 2014 the then Minister for Small Business commissioned Professor Ian Harper to lead a panel to undertake a broad ranging review of competition policy, ${ }^{30}$ the first such review since the Hilmer Report. ${ }^{31}$

The panel reported on 31 March 2015, ${ }^{32}$ providing the government with wide-ranging recommendations covering all areas of competition policy and administration. The sections on access and choice in high-quality health, education and community services - areas not often seen at the forefront of competition policy reform - had the potential to be a real game changer, but they are not the areas I am focusing on here.

The following summary of a cross-section of recommendations demonstrates the scope of the law reforms the Harper Panel recommended:

- legislative frameworks and government policies and regulations that bind the public and private sectors should not restrict competition; ${ }^{33}$

- cost-reflective road pricing, with independent oversight; ${ }^{34}$

- an overarching review of intellectual property law, including the contentious competition law exemption; $;^{35}$

- removal of restrictions on competition in state and territory planning and zoning laws unless they result in a net benefit; ${ }^{36}$

- removal of remaining restrictions on retail trading hours; ${ }^{37}$

- removal of restrictions on parallel imports unless the restrictions produce benefits that outweigh the costs and those benefits cannot be achieved in less restrictive ways; ${ }^{38}$ and

30 Media Release by the Hon Bruce Billson MP, 27 March 2014, bfb.ministers.treasury.gov.au/ media-release/014-2014/.

31 Sir Darryl Dawson had led a more limited review in 2003: see Review of the Competition Provisions of the Trade Practices Act (The Dawson Review), tpareview.treasury.gov.au/content/report.asp.

32 Competition Policy Review Final Report, March 2015, competitionpolicyreview.gov.au/final-report/.

33 Ibid. Recommendation 1. The government supported this recommendation.

34 Ibid. Recommendation 3. The government supported this recommendation.

35 Ibid. Recommendations 6 and 7. On 18 August 2005 the then treasurer instructed the Productivity Commission to conduct such a review 'to ensure that the intellectual property system provides appropriate incentives for innovation, investment and the production of creative works while ensuring it does not unreasonably impede further innovation, competition, investment and access to goods and services': www.pc.gov.au/inquiries/current/intellectual-property/terms-of-reference.

36 Ibid. Recommendation 9. The government supported this recommendation but noted that it is a state and territory responsibility.

37 Ibid. Recommendation 12. The government supported this recommendation but noted that it is a state and territory responsibility.

38 Ibid. Recommendation 13. The government supported this recommendation in part. 
- removal of current legal restrictions on pharmacy ownership and location in the long term interests of consumers. ${ }^{39}$

The Harper Panel reaffirmed that, if Australia is to improve economic performance, there is much that can and should be done in relation to competition policy, and therefore law reform in this area. Indeed, a concerted effort on law reform in the competition policy area is crucial if Australia is to achieve the outcomes foreshadowed in its G20 Comprehensive Growth Plan: to 'raise Australia's economic growth potential, create one million new jobs over the next five years ... and support continued improvements in national living standards'.

It is trite to observe that law reform is never easy. When reforms are proposed there are inevitably winners and losers. There is a fine balance to be struck by governments, weighing the benefits likely to be achieved against the costs to be imposed on those who enjoy the protections of the law as it currently stands. Nowhere is this more apparent than in relation to the law reform proposals the Harper Panel recommended. One example stands out.

Notwithstanding the breadth of the Harper recommendations, almost all of which were accepted in principle by the government and most of which are controversial, the recommendation that drew the most public comment was for changes to the law on misuse of market power. ${ }^{40}$ The battle over this law provides an interesting example of the challenges in delivering law reform.

The Harper Panel's consideration of the current misuse of market power law reenlivened a debate Australia has been having, on and off, for over 40 years. The current provision, introduced in $1974,{ }^{41}$ prohibits firms with market power using that power for the purpose ${ }^{42}$ of damaging competitors, preventing competitors entering a market, or deterring competitors from engaging in competitive conduct.

39 Ibid. Recommendation 14. The government noted the recommendation.

40 Competition and Consumer Act 2010 s 46.

41 Section 46. The provision originally appeared in the Trade Practices Act 1974. Although amendments were made in 1986, 2007 and 2008, they did not affect the essential features relevant to this chapter.

42 For the meaning of 'purpose', in this context, see Melway Publishing Pty Ltd $v$ Robert Hicks Pty Ltd [2001] HCA13; (2001) 205 CLR 1 at [31]; Universal Music Australia Pty Ltd v ACCC [2003] FCAFC 193; (2003) ATPR 41-947 at [256]. 
Those who supported changing s 46 argue that the provision is wrongly directed at competitors rather than protecting the competitive process, and that it is out of step with modern competition law in other countries which focuses on the effect of market power on the competitive process, not on a firm's subjective purpose. ${ }^{43}$ Further, they argued that the current law results in under-capture of exclusionary conduct, because it requires a court to determine whether a firm is using its market power (and not any other power it may have), by considering whether a firm that does not have market power would likely behave as the firm under investigation has acted. ${ }^{44}$ Those who argued for the status quo asserted that the provision, particularly the requirement to establish that the firm had taken advantage of its power, appropriately distinguished between procompetitive and anticompetitive conduct, and that the changes proposed would have unintended adverse consequences for consumers.

The Harper Panel supported change. They recommended that the prohibition should focus on protecting the competitive process - on conduct by firms with market power that has the purpose, effect or likely effect of substantially lessening competition. ${ }^{45}$ The Harper Panel also recommended that the courts should be required to mitigate against inadvertently capturing pro-competitive conduct, by having regard to the extent to which the conduct has the purpose, effect or likely effect of both increasing competition (including by enhancing efficiency, innovation, product quality or price competitiveness) and lessening competition (including by preventing, restricting or deterring the potential for competitive conduct or new entry).

However, the recommendation that the prohibition should focus on protecting the competitive process brought strident and vocal opposition from some within the business community. Objections were so strong that the government deferred a decision on the recommendation, deciding instead to undertake further consultations before making a decision. On 11 December 2015 the treasurer issued a discussion paper with six

43 See ACCC v Pfizer Australia Pty Ltd [2015] FCA 113.

44 See Rural Press Ltd v ACCC [2003] HCA 75; 216 CLR 53 and Competition and Consumer Act 2010 s $46(6 \mathrm{~A})(\mathrm{c})$.

45 Competition Policy Review, above n 31. Recommendation 30, 348. For an explanation of the phrase 'substantially lessen competition', see Miller's Australian Competition and Consumer Law Annotated (Thomson Reuters, 38 ${ }^{\text {th }}$ edn, 2016) [1.45.60]. 
options for change, including that recommended by the Harper Panel. ${ }^{46}$ Submissions on the options were called for and the assistant treasurer convened two roundtable sessions attended by representatives of small and large business and the Law Council of Australia. In all, 86 written submissions were received, arguing strongly for or against change. ${ }^{47}$ As one submission correctly put it: ${ }^{48}$ "There are two deeply entrenched, vigorous and irreconcilable positions being taken on the Harper Review's recommendation to amend Section 46'.

Although there was a sharp divide, neither point of view could be said to be entirely right or entirely wrong. The concerns of some of those opposing change were overstated, and the expectations of many who supported change were overly optimistic. The fact is that this is a very complex area of economic regulation. There is no bright line rule for determining what is, and what is not, exclusionary conduct that adversely affects the competitive process. ${ }^{49}$ However, international experience shows that a law that focuses on conduct that adversely affects the competitive process presents the best approach in this vexed area.

In the end the government decided to accept the Harper recommendation, in what would seem to be a triumph for good public policy because the focus of the law should be on exclusionary conduct that adversely affects the competitive process. On 16 March 2016 the Prime Minister announced that the government would proceed with an exposure draft of legislation to fully implement the Harper Panel's recommendation, stating that: ${ }^{50}$

The Government is committed to fixing Australia's competition policy and the amendment of Section 46 to deal with unilateral anti-competitive conduct is an important step to ensure Australia has the best possible competition framework to support innovation and boost economic growth and jobs.

46 The options paper is accessible at www.treasury.gov.au/ /media/Treasury/Consultations $\% 20$ and\%20Reviews/Consultations/2015/Options\%20to\%20strengthen\%20the $\% 20$ misuse $\% 20$ of $\% 20$ market\%20power\%20law/Key\%20Documents/PDF/dpoptions_marketpowerlaw.ashx.

47 The public submissions are available at www.treasury.gov.au/ConsultationsandReviews/ Consultations/2015/Options-to-strengthen-the-misuse-of-market-power-law/Submissions.

48 Submission by John Dahlsen, JC Dahlsen Pty Ltd, 28.

49 See, for example, Novel Inc v Microsoft Corporation [2013-2] Trade Cases 78,523 at 128,271.

50 Prime Minister's media release 16 March 2016 at www.pm.gov.au/media/2016-03-16/jointmedia-statement-fixing-competition-policy-drive-economic-growth-and-jobs. 
Few would disagree with those objectives - but the vigorous debate over s 46 illustrates that there is no single right or wrong way to reform this law to achieve them.

Finally, on 1 December 2016, the government introduced legislation ${ }^{51}$ to replace $s 46$ in accordance with the Harper Panel recommendation. The Senate Economics Legislation Committee considered the Bill and reported in February 2017, ${ }^{52}$ with members divided on party lines on whether or not to support the initiative. The majority agreed that $s 46$ is unfit for purpose because it has not provided adequate protection for nondominant firms. ${ }^{53}$ The minority, while welcoming 'strong competition policy', thought that the change would add a 'new layer of red tape' deterring job-creating investment in Australia. ${ }^{54}$ However, the Bill was passed on 23 August 2017 to come into effect later in 2017..$^{55}$

To conclude the journey by returning to consumer law reform, on 31 March 2016 the Minister for Small Business and assistant treasurer published a review of the Australian Consumer Law..$^{56}$ That review, briefed by the minister ${ }^{57}$ to consider whether or not 'the law is operating as intended and addresses the risk of consumer detriment without imposing unnecessary red tape', ${ }^{58}$ recommended 18 changes to the Australian Consumer Law, including a significant increase in penalties for contravention.

With that report and the pending legislation to implement the Harper Panel recommendations, we continue on the road to improving Australian society through law reform in the areas of competition and consumer law and policy.

51 Competition and Consumer Amendment (Misuse of Market Power) Bill 2016. A second Bill was introduced on 30 March 2017 to implement other Harper Panel recommendations supported by the government: Competition and Consumer Amendment (Competition Policy Review) Bill 2017.

52 The Senate Economics Legislation Committee, Competition and Consumer Amendment (Misuse of Market Power) Bill 2016 Report, February 2017, www.aph.gov.au/Parliamentary_Business/ Committees/Senate/Economics/Misuseofmarketpower16/Report.

53 Report, paras 2.74, 2.75 .

54 Report, paras 1.27, 1.28.

55 Competition and Consumer Amendment (Misuse of Market Power) Act 2017 (Cth).

56 consumerlaw.gov.au/review-of-the-australian-consumer-law/final-report/.

57 Media Release by the Hon Kelly O’Dwyer MP, 31 March 2016, kmo.ministers.treasury.gov.au/ media-release/029-2016/.

58 'Australian Consumer Law Fact Sheet 2', consumerlaw.gov.au/files/2016/03/ACL_Review _FS2.pdf. 
This text is taken from New Directions for Law in Australia: Essays in Contemporary Law Reform, edited by Ron Levy, Molly O’Brien, Simon Rice, Pauline Ridge and Margaret Thornton, published 2017 by ANU Press, The Australian National University, Canberra, Australia. 